\title{
Chapter 13 \\ Understanding the Multidimensionality of Climate-Smartness: Examples from Agroforestry in Tanzania
}

\author{
Anthony A. Kimaro, Ogossy G. Sererya, Peter Matata, Götz Uckert, \\ Johannes Hafner, Frieder Graef, Stefan Sieber, and Todd S. Rosenstock
}

\subsection{Introduction}

Persistent and resilient food insecurity afflicts smallholder farmers throughout much of East and Southern Africa, including Tanzania, where more than $80 \%$ of people in rural areas are involved in agriculture and charcoal production (Rioux et al. 2017; Mwampamba 2007). With such a large proportion of the population involved, agriculture in Tanzania acts as an economic driver of the national economy and presents a way out of poverty (Hansen et al. 2018). However, rural livelihoods in Tanzania are at risk. Farmland is near universally rain-fed, and already susceptible to droughts and weather variability. While current predictions indicate

\footnotetext{
A. A. Kimaro $(\triangle)$

World Agroforestry Centre (ICRAF), Tanzania Programme, Dar es Salaam, Tanzania

Leibniz Centre for Agricultural Landscape Research (ZALF), P. Müncheberg, Germany e-mail: a.kimaro@cgiar.org

O. G. Sererya

Ministry of Natural Resource and Tourism, Morogoro, Tanzania

P. Matata

Tumbi Agricultural Research Institute and Training Institute, Tabora, Tanzania

G. Uckert · J. Hafner · F. Graef · S. Sieber

Leibniz Centre for Agricultural Landscape Research (ZALF), P. Müncheberg, Germany e-mail: uckert@zalf.de; johannes.hafner@zalf.de; fgraef@zalf.de; stefan.sieber@zalf.de

T. S. Rosenstock

World Agroforestry Centre (ICRAF), Tanzania Programme, Dar es Salaam, Tanzania

ICRAF/CGIAR Research Program on Climate Change, Agriculture and Food Security (CCAFS), Kinshasa, Democratic Republic of the Congo

e-mail: T.Rosenstock@cgiar.org
} 
that, on average, Tanzania will have future rainfall totals approximately equivalent to today, seasons may shift and the predictability of precipitation will decline (International Center for Tropical Agriculture and World Bank 2017). There is already a need to help farmers to prepare for today's variable precipitation. And coping with today's conditions will help farmers adjust better to changes in the future.

Increasing the rate of adoption of improved agricultural technologies can help build resilience to weather-related risks. For example, Kimaro et al. (2015) examined the resilience of productivity across four seasons within conventional and conservation agriculture in the highlands of central Tanzania and found higher yields and lower interannual variation across all permutations of conservation agriculture in comparison to the control. Furthermore, rainwater use efficiency (RUE) and soil moisture retention were found to be higher in conservation farming and intercropping practices in Tanzania versus traditional practices (Kizito et al. 2016). These results suggest that improved technologies can increase resilience, especially in areas with lower than average rainfall and persistent drought.

However, the adoption of improved technology may affect more than just the resilience of the farming system. It may also affect the system's productivity, including both yields of edible and non-edible crop products and incomes (Charles et al. 2013). Furthermore, it may change the environmental sustainability of the production system; for instance, the climate change mitigation potential, by either sequestering carbon in biomass and/or soils and/or reducing greenhouse gas emissions (Kaonga and Bayliss-Smith 2009). The multidimensionalities of impacts with agricultural change are fundamental to climate-smart agriculture (CSA), which aims to achieve three goals simultaneously: sustainably increase production, improve resilience and mitigate climate change.

Despite multiple goals, rarely are CSA practices evaluated in ways that cross more than one of these three objectives (Rosenstock et al. this volume). This is important for development practitioners because it limits the evidence with which to evaluate potential trade-offs and increases the likelihood of unintended consequences with development programming (Lamanna et al. 2016). Comprehensive information that addresses multiple objectives is needed to evaluate changes in agricultural systems. That, however, is easier said than done, because research is typically undertaken for specific purposes without these three factors in mind, and the costs of multi-indicator measurements may be prohibitive.

We present data from three previously unpublished experiments in two regions of Tanzania: two near Dodoma and one near Tabora. Dodoma has a semiarid climate with a unimodal rainfall regime (7 to 8-month dry period) and mean annual precipitation of 560 millimetres (mm) (Kimaro et al. 2009). Tabora is subhumid with mean annual precipitation of $928 \mathrm{~mm}$ (Nyadzi et al. 2003). The experiments in both sites use pigeonpea -based intercropping systems. Here, we present examples of how scientists can investigate CSA in multidimensional assessments. 


\subsection{Production and Mitigation Benefits of Agroforestry and Intercropping Practices in Dodoma}

In arid and semiarid areas of Tanzania, food crops and fuelwood are both the product of agricultural landscapes. Thus, issues of food, fuel and climate are inherently linked and may be best addressed together. Agroforestry-specifically, shelterbelt, G.sepium intercropping, and border plantings of fuelwood and food crops-has been promoted to address these concerns simultaneously. In theory, this technology may be climate-smart. Growing trees and crops together has been shown to have positive, negative and no effect on crop productivity (Coe et al. 2016). For instance, intercropping maize with 'fertiliser trees' such as G. sepium and/or pigeonpea (Cajanus cajan) improves land productivity, soil fertility and enhances the ability of the land to capture and store rainfall, creating resilient cropping systems (Sileshi et al. 2011; Kimaro et al. 2016). Lastly, production of fuelwood reduces collection from natural areas as well as deforestation and degradation (Ramadhani et al. 2002). The mitigation benefits may be further enhanced when coupled with improved cook stove (ICS) technologies that increase the efficiency of fuelwood use. Thus, assessing the synergies of on-farm wood production using agroforestry along with ICS technology increases our understanding of the multidimensional impacts of CSA; yet the impacts of these technologies have often been evaluated separately. We conducted studies to evaluate the CSA benefits of on-farm wood supply and its efficient use by ICS as well as crop yields under agroforestry and maize-pigeonpea intercropping in Kongwa and Chamwino districts, Dodoma, Tanzania.

The first study assessed wood supply from agroforestry technologies (shelterbelts, boundary tree planting, contours planting, and Gliricidia sepium intercropping), established on nearly 110 farmers' fields, to evaluate the climate-smartness of these technologies in Chamwino (Ilolo village) and Kongwa (Molet, Mlali Laikala and Chitego villages) districts. Fuelwood yield was determined using speciesspecific biomass equations (Sererya et al. 2017) and household wood consumption was assessed using the kitchen performance test (Uckert et al. 2017). While it has been found that greenhouse gas (GHG) emissions reduced through the use of the ICS (Sererya 2016), the offset of carbon dioxide emissions by using fuelwood produced on-farm was used to assess the mitigation impacts of ICS and agroforestry technologies. Crops production in alleys between shelterbelts was determined through the systematic sampling of small plots.

We found evidence that agroforestry met some components of CSA. Maize grain yield in the alleyways between shelterbelt strips ranged from 2.3 to 3.2 tons per hectare $\left(\mathrm{t} \mathrm{ha}^{-1}\right)$. Crop yields declined slightly in shelterbelt areas under the influence of trees, but were similar in yield to that obtained in maize monoculture in Dodoma (Kimaro et al. 2009). Wood biomass production in shelterbelt, farm boundaries, intercropping and on contour bounds ranged from 0.5 to $8 \mathrm{t} \mathrm{ha}^{-1}$, depending on the species and spacing adopted (Table 13.1). This amount of wood can sustain a fivemember family for 4-6 years when using the traditional three-stone firewood (TSF) stove and ICS, respectively (Table 13.1). Relative to the TSF, households using ICS 
Table 13.1 Wood yields and consumption time (months) for different agroforestry technologies in Chamwino and Kongwa Districts, Tanzania

\begin{tabular}{l|l|l|l|l|l}
\hline Technology & Tree species & Spacing $(\mathrm{m})$ & Wood $\left(\mathrm{t} \mathrm{ha}^{-1}\right)$ & ICS $^{\mathrm{a}}$ & TFS $^{\mathrm{a}}$ \\
\hline \multirow{3}{*}{ Boundary } & Acacia polyacantha & $2 \times 2$ & 4.41 & 3.5 & 2.4 \\
\cline { 2 - 6 } & Eucalyptus camadulensis & $2 \times 2$ & 7.70 & 6.1 & 4.2 \\
\hline \multirow{3}{*}{ Woodlots } & Grevillea robusta & $2 \times 2$ & 2.64 & 2.1 & 1.4 \\
\cline { 2 - 6 } & Senna siamea & $3 \times 3$ & 1.01 & 0.8 & 0.6 \\
\cline { 2 - 6 } & Melia azadirachta & $4 \times 4$ & 0.84 & 0.7 & 0.5 \\
\hline \multirow{3}{*}{ Shelterbelt } & Grevillea robusta & $3 \times 3$ & 0.46 & 0.4 & 0.3 \\
\cline { 2 - 7 } & Gliricidia sepium & $1 \times 2$ & 2.08 & 1.6 & 1.1 \\
\hline \multirow{2}{*}{ Intercropping } & Gliricidia sepium & $3 \times 3$ & 1.34 & 1.1 & 0.7 \\
\hline
\end{tabular}

${ }^{a}$ Duration of time (years) it will take for a household of five members to complete the amount of wood produced on-farm. The estimate is based on a household consumption rate of $5 \mathrm{~kg}$ per day when using the traditional TSF (Uckert et al. 2017)

consumed 23\% less firewood, which resulted in a reduction in fuelwood collection time (32\%) as well as cooking time (20\%) (Uckert et al. 2017). However, firewood and time consumption vary between different foods cooked (Hafner et al. 2018). The reduction of GHG emissions (carbon monoxide, carbon dioxide and particulate organic matter) by the ICS technology, relative to TSF, ranged from $60 \%$ to $62 \%$ (Sererya 2016). The costs of fuelwood used in ICS and TSF in Dodoma is estimated at Tanzanian Shilling (TZS) 15,984 (United States Dollar (USD) 7.2) and TZS 32,940 (USD 14.8), respectively (Sererya 2016). Based on these estimates, the economic benefits (in terms of cost savings) of on-farm wood supply ranged from USD 90 to $750 \mathrm{ha}^{-1}$, depending on the tree species and planting spacing adopted. These results suggest that diversification of production (crops and wood) options and income sources through agroforestry contribute in building community resilience (adaptive capacity) as noted by Charles et al. (2013).

We did not measure directly the resilience benefits of the agroforestry systems. Neither the interannual variability of production nor explicit indicators of proxies for resilient agroecosystems (soil carbon, biodiversity, resource efficiency etc.) were available. The former because of the short timeframe of the research and the latter because the research was designed for other purposes. Increasing the duration of research would have helped provide more robust evidence, as would collecting a wider range of indicators. This agrees with early assessments of the literature available in Tanzania (Lamanna et al. 2016) and, therefore, we suggest research protocols for CSA need to be more inclusive to capture specific measures of resilience.

'Mother' and 'baby' research designs were used in Malawi to examine effects across heterogeneous conditions (Snapp 2002). In this study, the mother trial $(\mathrm{N}=15)$ - or replicated on-farm experiments—were laid out in a randomised complete block design and were managed by researchers. Baby trials $(\mathrm{N}=275)$ - or farmer-managed demonstrations of maize-pigenopea intercropping - took place in farmers' fields to allow for participatory evaluation of the technology. Mother trial had five treatments including the control, and the baby trial had maize-pigeonpea intercropping and maize monoculture as a control. 
Table 13.2 Maize grain yields $\left(\mathrm{t} \mathrm{ha}^{-1}\right)$ in different intercropping combinations with pigeonpea (PP) at Mlali and Chitego villages, Kongwa district, Dodoma, Tanzania

\begin{tabular}{l|l|l|l|l}
\hline \multirow{2}{*}{ Maize-PP ratio $^{\mathrm{a}}$} & \multicolumn{2}{|l|}{} & \multicolumn{2}{l}{2016} \\
\cline { 2 - 5 } & Mlali & Chitego & Mlali & Chitego \\
\hline MM & $2.04 \mathrm{a}$ & $3.25 \mathrm{a}$ & $2.92 \mathrm{a}$ & $3.53 \mathrm{a}$ \\
\hline $1 \mathrm{M}: 1 \mathrm{PP}$ & $1.21 \mathrm{a}$ & $2.26 \mathrm{ba}$ & $2.53 \mathrm{ba}$ & $2.99 \mathrm{a}$ \\
\hline $1 \mathrm{M}: 2 \mathrm{PP}$ & $1.46 \mathrm{a}$ & $1.24 \mathrm{~b}$ & $1.77 \mathrm{~b}$ & $2.35 \mathrm{a}$ \\
\hline $2 \mathrm{M}: 1 \mathrm{PP}$ & $1.39 \mathrm{a}$ & $3.19 \mathrm{a}$ & $2.14 \mathrm{ba}$ & $2.70 \mathrm{a}$ \\
\hline Mean & 1.52 & 2.49 & 2.34 & 2.89 \\
\hline
\end{tabular}

aPlanting ratios tested were: alternate rows of maize and pigeonpea (1M:1M), one maize row and two pigeonpea rows (1M:2PP), two maize rows and one pigeonpea row (2M:1PP) and monocultures of maize (MM) and pigeonpea as controls

Table 13.3 LER for maize (M) and pigeonpea (PP) intercropping at Mlali and Chitego villages, Kongwa district, Dodoma, Tanzania

\begin{tabular}{l|l|l|l|l}
\hline \multirow{2}{*}{ Maize-PP ratio $^{\mathrm{a}}$} & \multicolumn{2}{|l|}{} & 2016 & \\
\cline { 2 - 5 } $2 \mathrm{M}: 1 \mathrm{PP}$ & Mlali & Chitego & Mlali & Chitego \\
\hline $1 \mathrm{M}: 1 \mathrm{PP}$ & 1.13 & 1.56 & 1.21 & 1.17 \\
\hline $1 \mathrm{M}: 2 \mathrm{PP}$ & 1.12 & 1.47 & 1.46 & 1.53 \\
\hline
\end{tabular}

aplanting ratios tested were: alternate rows of maize and pigeonpea(1M:1M), one maize row and two pigeonpea rows (1M:2PP), two maize rows and one pigeonpea row (2M:1PP) and monocultures of maize and pigeonpea as controls

Results of this intercropping experiment showed key challenges in understanding what is and isn't CSA. Productivity in farmer-managed baby trials in three villages (Laikala, Mlali and Chitego) ranged from 1.2 to $3.2 \mathrm{t} \mathrm{ha}^{-1}(>150 \%)$, suggesting variations in site and weather conditions. Laikala and Mlali are lower potential sites due to greater degradation while Chitego is a higher potential site for crop production (Kimaro et al. 2015). Overall, maize yield in baby trials across sites was 50\% higher than the farmer practice yield of $1.5 \mathrm{t} \mathrm{ha}^{-1}$ in the same areas (Kimaro et al. 2012). However, productivity benefits were by no means universal across all planting arrangements and agroecologies. Apart from an intercropping combination-on a one-to-one (1:1) ratio-maize grain yield was reduced by pigeonpea intercropping (Table 13.2). This yield suppression of one component in the mixture was offset when considering farm-level productivity, as reflected by the land equivalent ratio (LER) of greater than one (Table 13.3). Moreover, the intercropping arrangement with higher legume proportions of pigeonpea than maize (1:2 ratio of maize to pigeonpea) was more beneficial to farmers at Mlali village, a lower potential site $(\mathrm{LER}=1.46)$ than in Chitego village, a high potential site ( $\mathrm{LER}=1.24)$; but only in the year of poor precipitation and yields (Table 13.3). These findings demonstrate the importance of adopting research protocols that have sufficient temporal and spatial representation to get less spurious results. In this trial, pigeonpea - a droughtresistant crop relative to maize-determines farm-level productivity benefit within the mixture under harsh conditions; reflecting improved resilience due to diversifi- 
cation with drought-tolerant crops. Accordingly, we found the 1:1 arrangement (maize/pigeonpea) - the common farmer practice- to be less sensitive to site and year heterogeneity, suggesting greater resilience. Lastly, the use of LERs to quantify value for the farmer allows the combination of multiple farm outputs and, thus, provides a way to compare monoculture to polycultures. Our results show mixed results when describing yield, but clear benefits of intercropped agroforestry in terms of increased productivity and decreased variance when quantified with LERs (a more comprehensive measure), highlighting the importance of selecting appropriate indicators when studying CSA.

\subsection{Production and Resilience Benefits of Cassava-Based Intercropping Practices in Tabora}

Cassava is the third most important food crop, after maize and rice, in Urambo and Uyui districts, Tabora region. It is also a more drought-resistant crop than maize and rice (de Oliveira et al. 2017). Most farmers use this crop as a safety net for food shortages, especially in years with prolonged drought. At the same time, intercropping has potential to mitigate soil fertility issues. The added biomass to soils under the cassava-based intercropping system often improves fertility, acidity and soil structure, especially when leguminous species such as pigeonpea are used (Makumba et al. 2009). Thus, cassava-legume intercropping was tested as a strategy for diversifying production and/or income sources as well as building biological quality in these villages.

We evaluated the resilience and productivity aspects of cassava farming under monoculture, intercropping and rotations with pigeonpea in Mbola, Itebulanda and Utenge villages. The research followed a mother-baby plot approach (Snapp 2002), with a researcher-managed plot in each village. Then, ninety farmer-managed plots (baby plots) were set up across the three villages. There was also an on-station experiment at the research farm of the Agricultural Research Institute (ARI) in Tumbi. At the research and mother plots, each treatment was replicated three times in a randomised complete block design; while treatments at the baby plots were unreplicated. Measures of yield, soil moisture and RUE were used as indicators of productivity and resilience. Mitigation was not estimated.

Yields of intercropping treatments (Canavalia, Cowpea and Pigeonpea), by comparison to the control, were reduced by $78.5 \%, 58 \%$ and $43 \%$ respectively in the research site at the ARI (Table 13.4). The greater reduction in yield in mother plots provides some indication of the differences between research and farmermanaged implementations of these trials. Similar results were also noted for cassava yields intercropped with pigeonpea $(50 \%)$ and cowpea $(60 \%)$ by farmers in their baby trial. Such a difference has broad implications for our understanding of the ability of management practices to generate resilience and livelihood benefits, as the vast majority of the data available to evaluate the climate-smartness of technologies was generated on the research stations (Rosenstock et al. this volume). Intercropping 
Table 13.4 Growth and yield of cassava at the on-farm ('mother') trials in Urambo and Uyui districts, Tabora, Tanzania

\begin{tabular}{l|l|l|l}
\hline Treatments & Survival $(\%)$ & Yield $\left(\mathrm{tha}^{-1}\right)$ & RUE $\left(\mathrm{kg}^{-1} \mathrm{ha}^{-1} \mathrm{~mm}^{-1}\right)$ \\
\hline Cassava + Cannavalia & $84.3 \mathrm{a}^{2}$ & $2.0 \mathrm{c}$ & $4.0 \mathrm{c}$ \\
\hline Cassava + Cowpea & $88.2 \mathrm{ab}$ & $3.9 \mathrm{~b}$ & $8.1 \mathrm{cb}$ \\
\hline Cassava + Pigeonpea & $86.9 \mathrm{ab}^{\mathrm{a}}$ & $5.3 \mathrm{~b}$ & $10.9 \mathrm{~b}$ \\
\hline Cassava monoculture & $89.2 \mathrm{~b}$ & $9.3 \mathrm{a}$ & $19.4 \mathrm{a}$
\end{tabular}

${ }^{1}$ RUE = Rainwater Use Efficiency. ${ }^{2}$ Means within a column bearing similar letter(s) are not statistically different at $5 \%$ level of probability based on the Duncan's multiple range test $(n=3)$

effects on RUE were similar to those on yield (Table 13.4). Comparatively low soil moisture content in intercropping treatments compared to monoculture (data not shown) suggests competition on soil moisture, which resulted in reduced yield and RUE. Apparently, monocultures of drought-tolerant crops, like cassava, provide a promising strategy to enhance farm production and to build resilience, while minimising the negative effects of intercropping. The most promising crop combinations need to be identified after more seasons (crop rotations).

This study has only been conducted for one season so far. However, it already illustrates the importance of offering CSA options from a farmer-centric perspective. Preliminary results suggest that cassava is sensitive to competition, and yields may be adversely affected by intercropping, especially in seasons with low and sporadic precipitation, like in 2017. Thus, despite the best intentions, cassava intercropping may not be climate-smart in this area and, perhaps, farmers are better off by diversifying into cassava monocultures, cassava-legume rotation if they want to diversify out of maize.

\subsection{Implications for Development}

This chapter analyses the benefits and trade-offs of three agroforestry and intercropping practices in two agroecologies to build evidence for CSA scaling in Tanzania. The analysis involved on-farm wood supply using shelterbelts, intercropping and contours technologies as well as crops production and the resilience effects of pigeonpea -based intercropping systems in semiarid Dodoma and subhumid Tabora. Integrating on-farm wood production and ICS contributed to meeting the multiobjectives of CSA through improved wood supply to meet household annual demand and reducing GHG emissions (less than 60\% relative to TSF) as well as productive time lost in cooking and searching for firewood. Moreover, crop diversification at the appropriate intercropping combinations enhanced crop yield (maize and pigeonpea) and agroecosystem resilience as noted by higher LER in the 1:1 ratio across sites. Plant combinations with higher proportions of pigeonpea conferred greater resilience, especially in seasons with less precipitation, which demonstrates the significance of selecting for drought-resistant crops and appropriate farm management practices (i.e., planting combinations/density) in building resilient 
farming systems. The suppression of yields of intercropped cassava (43-79\%) during the first season suggests that the benefits of intercropping may take time to be realised and/or may be comprised by the poor selection of companion crops and farm management practices, such as intercropping, crop rotation, and plant spacing. Trends of CSA benefits in research and farmer-managed experiments were similar, although absolute values of yields (maize, cassava or fuelwood) were higher in research plots. Thus, participatory evaluation of technology is critical for validating and downscaling research results under farmer management conditions and for farmers to appreciate the benefits of CSA prior to wide scaling. Overall results of our analysis of CSA benefits illustrate key principles when considering the multidimensionality of CSA, including the need to: select appropriate indicators, ensure designs are robust for heterogeneity, examine trade-offs, and conduct participatory evaluation of CSA on farmers' field sites. Together, these factors provide more robust evidence for CSA programming and help practitioners and policymakers to be on the lookout for such issues and support evidence-based scaling initiatives. Unfortunately, so many practices and technologies have been labeled CSA in the past few years that some would say it is just rebranding. Accounting for the principles highlighted here, and explicitly considering the multidimensionality of CSA objectives in decision-making, will go a long way to improving implementation and achieving outcomes for farmers.

Acknowledgements We thank Nictor Namoi and Mary Ng'endo for conducting focus group discussions in Tabora as well as farmers and extension officers in Chamwino and Kongwa Districts for supporting this study. The participatory CSA trials in Tabora were funded by the United States Department of Agriculture Foreign Agricultural Service and is part of the CGIAR Research Program on Climate Change, Agriculture and Food Security's Partnerships for Scaling Out Climate-Smart Agriculture project. Research in Kongwa district, Dodoma was funded by the United States Agency for International Development's Feed the Future initiative through Africa RISING; while in Chamwino District, Dodoma it was funded by Deutsche Gesellschaft für Internationale Zusammenarbeit (GIZ) as ICRAF support to Trans-SEC and was co-financed by Bundesministerium für Bildung und Forschung (BMBF) and Bundesministerium für wirtschaftliche Zusammenarbeit und Entwicklung (BMZ). The views expressed in this chapter are those of the authors and may not under any circumstances be regarded as stating official positions of the funders.

\section{References}

Charles RL, Munishi PKT, Nzunda EF (2013) Agroforestry as adaptation strategy under climate change in Mwanga District, Kilimanjaro, Tanzania. Int J Environ Protect 3(11):29-38

Coe R, Njoloma J, Sinclair F (2016) Loading the dice in favour of the farmer: reducing the risk of adopting agronomic innovations. Exp Agric:1-17. https://doi.org/10.1017/S0014479716000181

Hafner J, Uckert G, Graef F et al (2018) A quantitative performance assessment of improved cooking stoves and traditional three-stone-fire stoves using a two-pot test design in Chamwino, Dodoma, Tanzania. Environ Res Lett 13(2):025002

Hansen J, Hellin J, Rosenstock T , Fisher E, Cairns J, Stirling C, Lamanna C, van Etton J, Rose A, Campbell B (2018) Climate risk management and rural poverty reduction. Agric Syst. https:// doi.org/10.1016/j.agsy.2018.01.019. 
International Center for Tropical Agriculture, World Bank (2017) Climate-smart agriculture in Tanzania. CSA country profiles for Africa series. CIAT, World Bank, Washington, DC

Kaonga M, Bayliss-Smith TP (2009) Carbon pools in tree biomass and the soil in improved fallows in eastern Zambia. Agrofor Syst 76:37-51

Kimaro AA, Timmer VR, Chamshama SOA (2009) Competition between maize and pigeonpeain semi-arid Tanzania: effect on yields and nutrition of crops. Agric Ecosyst Environ 134:115-125

Kimaro AA, Sileshi GW, Mpanda M et al (2012) Evidence-based scaling-up of evergreen agriculture for increasing crop productivity, fodder supply and resilience of the maize-mixed and agro-pastoral farming systems in Tanzania and Malawi. https://cgspace.cgiar.org/handle/1056 8/16883? show=full Accessed

Kimaro AA, Mpanda M, Meliyo JL et al (2015) Soil related constraints for sustainable intensification of cereal-based systems in semi-arid central Tanzania. Proceedings of the Tropentag conference, Berlin, 16-18 September 2015. http://www.tropentag.de/2015/abstracts/full/1005.pdf

Kimaro AA, Mpanda M, Rioux J et al (2016) Is conservation agriculture 'climate-smart' for maize farmers in the highlands of Tanzania? Nutr Cycl Agroecosyst 105:217-228

Kizito F, Lukuyu B, Sikumba G et al (2016) The role of forages in sustainable intensification of crop-livestock agro-ecosystems in the face of climate change: the case for landscapes in Babati, Northern Tanzania. In: Lal R et al (eds) Climate change and multi-dimensional sustainability in African agriculture. https://doi.org/10.1007/978-3-319-41238-2_22

Lamanna C, Namoi N, Kimaro A et al (2016) Evidence-based opportunities for out-scaling climate-smart agriculture in east Africa. CCAFS Working Paper no. 172. CGIAR Research Program on Climate Change, Agriculture and Food Security (CCAFS), Copenhagen. https:// ccafs.cgiar.org/publications/evidence-based-opportunities-out-scaling-climate-smart-agriculture-east-africa\#.Wp61VUx2vIU. Accessed

Makumba W, Akinnifesi FK, Janssen BH (2009) Spatial rooting patterns of gliricidia, pigeonpeaand maize intercrops and effect on profile soil $\mathrm{N}$ and $\mathrm{P}$ distribution in southern Malawi. Afr J Agric Res 4:278-288

Mongi H, Majule AE, Lyimo JG (2010) Vulnerability and adaptation of rain fed agriculture to climate change and variability in semi-arid Tanzania. Afr J Environ Sci Technol. https://doi. org/10.5897/AJEST09.207

Mwampamba TH (2007) Has the woodfuel crisis returned? Urban charcoal consumption in Tanzania and its implication for present and future forest availability. Energy Policy 35:4221-4234

Nyadzi GI, Janssen BH, Otsyina RM (2003) Water and nitrogen dynamics in rotational woodlots of five tree species in western Tanzania. Agrofor Syst 59(3):215-229

de Oliveira EJ, Morgante CV, de Tarso Aidar S et al (2017). Evaluation of cassava germplasm for drought tolerance under field conditions. Euphytica 213:188. https://doi.org/10.1007/ s10681-017-1972-7

Ramadhani T, Otsyina R, Franzel S (2002) Improving household income and reducing deforestation using rotational woodlots in Tabora district, Tanzania. Agric Ecosyst Environ 89(3):229-239

Rioux J, Lava E, Karttunen K (2017) Climate-smart agriculture guideline for the United Republic of Tanzania: a country-driven response to climate change, food and nutrition insecurity, Food and Agriculture Organization Policy Brief. FAO, Rome

Rosenstock TS, Mpanda M, Aynekulu E (2014) Targeting conservation agriculture in the context of livelihoods and landscapes. Agric Ecosyst Environ 187:47-51

Rowhania P, Lobellb DB, Lindermanc M (2011) Climate variability and crop production in Tanzania. Agric For Meteorol 151:449-460

Sererya OG (2016) Economic analysis of improved firewood cooking stove, its implication on rural livelihoods and environmental sustainability in Chamwino and Kilosa districts, Tanzania. MSc dissertation in Environmental and Natural Resource Economics, Sokoine University of Agriculture, Morogoro

Sererya OG, Kimaro A, Lusambo L (2017) Resilience and livelihood benefits of climate smart agroforestry practices in semi-arid Tanzania. www.tropentag.de/2017/abstracts/posters/960. pdf 
Sileshi GW, Akinnifesia FK, Ajayia OC (2011) Integration of legume trees in maize-based cropping systems improves rain use efficiency and yield stability under rainfed agriculture. Agric Water Manag 98:1364-1372

Snapp S (2002) Quantifying farmer evaluation of technologies: the mother and baby trial design. https://www.researchgate.net/publication/237370359_Quantifying_Farmer_Evaluation_of_ Technologies_The_Mother_and_Baby_Trial_Design. Accessed

Uckert G, Hafner J, Graef F et al (2017) Farmer innovation driven by needs and understanding: building the capacities of farmer groups for improved cooking stove construction and continued adaptation. Environ Res Lett. https://doi.org/10.1088/1748-9326/aa88d5 (in press)

F. Kizito, B. Lukuyu, G. Sikumba, J. Kihara, M. Bekunda, D. Bossio, K.W. Nganga, A. Kimaro, H. Sseguya, B. Jumbo and P. Okori. 2016. The Role of Forages in Sustainable Intensification of Crop-Livestock Agro-ecosystems in the Face of Climate Change: The Case for Landscapes in Babati, Northern Tanzania. In R. Lal et al. (eds.), Climate Change and Multi- Dimensional Sustainability in African Agriculture, https://doi.org/10.1007/978-3-319-41238-2_22

Open Access This chapter is licensed under the terms of the Creative Commons Attribution 4.0 International License (http://creativecommons.org/licenses/by/4.0/), which permits use, sharing, adaptation, distribution and reproduction in any medium or format, as long as you give appropriate credit to the original author(s) and the source, provide a link to the Creative Commons license and indicate if changes were made.

The images or other third party material in this chapter are included in the chapter's Creative Commons license, unless indicated otherwise in a credit line to the material. If material is not included in the chapter's Creative Commons license and your intended use is not permitted by statutory regulation or exceeds the permitted use, you will need to obtain permission directly from the copyright holder.

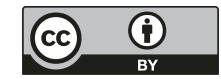

